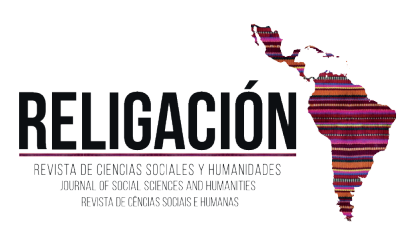

Sección Sur-Sur

\title{
The Impact of Environmental Factor on Kerman Economic Development in Ilkhanid Era
}

El impacto del factor ambiental en el desarrollo económico de Kerman durante el llkanato

\author{
Maryam Pourshir Mohammadi Roudsari | Persian Gulf University - IRAN | \\ PhD student in the history of Islamic Iran, Persian Gulf University, Bushehr, Iran. E-mail: maryamroudsary@gmail.com \\ Ali Rasouli | Persian Gulf University - IRAN | \\ Assistant Professor of History Department of Persian Gulf University, Bushehr, Iran (Correspondence-Author) E-mail: rasooli@pgu.ac.ir \\ Hamid Asad Pour | Persian Gulf University - IRAN | \\ Assistant Professor of History Department of Persian Gulf University, Bushehr, Iran. E-mail: asadpour121@yahoo.com
}

Mohammad Reza Gholizadeh | Persian Gulf University - IRAN |

Assistant Professor of History Department of Persian Gulf University, Bushehr, Iran E-mail: rezatarikh@pgu.ac.ir

\begin{abstract}
Natural phenomena are one of the influencing factors in the economic and social situation of human societies. However, it is clear that the mode and extent of this effect depends on the natural state of this or that area. On the other hand, Iran's historical events and circumstances appear to have been less studied geographically. The present study examines the probable impact of the natural phenomena of the Kerman province, their prominent and diverse natural and human characteristics on the sources of the lakhanan period. For this purpose, it uses the historical and geographical reports of the 7th and 8th centuries. The above findings are important in this regard, demonstrating the history of economic developments in Kerman and other parts of Iran should not affect only in light of human events.
\end{abstract}

Key Words: Historical Geography; Kerman; Economic state; Ilkhanan Age; Insecurity; Persian Gulf.

\section{RESUMEN}

Los fenómenos naturales son uno de los factores influyentes en la situación económica y social de las sociedades humanas. Sin embargo, está claro que el modo y el alcance de este efecto depende del estado natural de esta o aquella área. Por otro lado, los eventos y circunstancias históricas de Irán parecen haber sido menos estudiados desde una perspectiva geográfica. El presente estudio examina el probable impacto de los fenómenos naturales de la provincia de Kerman, sus características naturales y humanas prominentes y diversas en las fuentes del período lakhanan. Para este propósito, se sirve de los informes históricos y geográficos de los siglos VII y VIII. Los hallazgos anteriores son importantes a este respecto, lo que demuestra que la historia de los desarrollos económicos de Kerman y otras partes de Irán no deben considerarse solo a la luz de los acontecimientos humanos.

Palabras clave: Geografía histórica; Kerman; Estado económico; Edad de Ilkhanan; Inseguridad; Golfo Pérsico. 


\section{Introduction}

The relationship between natural geography and historical developments is one of the most controversial issues in historical research, as historical developments always occur in the context of geography, and without the geography of history it is not possible. Therefore, studying and studying the spatial or geographical context of events is important in historical research and contributes to a more comprehensive and accurate understanding of historical developments. In other words, the study of the history of an area cannot be preceded by a mere study of historical events.

This understanding is more accurately achieved through historical geographical science, which focuses on the knowledge of a particular region over a specific time period and examines the interaction between human beings, nature, and its cultural effects. (Quoted by Ahmadvand,Sauer, 1941: 15-17) Thanks to historical geography one can study human culture and indeed human geography (human habitat). (Quoted by Ahmadvand Sauer, 1941: 8) Historical geography follows two goals, first showing the impact of natural and geographical environments on human events, second examining human actions in the past. Simply put, historical geography examines particular areas at a particular time and explores the impact of the environment on the occurrence of historical events as well as the human achievements crystallized in the environment. (Ahmadvand, 2009: 63-41) In historical geography, ultimately human is an important and influential factor in historical geography and ultimately the creation of culture. (Quoted by Ahmadvand Sauer, 1941: 15) That is to say, the geographical conditions of each environment provide particular potentials and opportunities to the people who reside there, and these are the people who decide how to use or disregard those facilities. In fact, it is the human being who decides how to exploit the potential of his environment. This environmental capacity or potential environmental potential affects the political, social and economic status of an area. (Papeli Yazdi, 1994: 14)

The present study examines some aspects of the relationship between natural geography and economic situation in Kerman province in the Ilkhanid era, seventh and eighth centuries. The province of Kerman has outstanding natural features that make it an appropriate case study for investigating the relationship between the natural environment and historical developments. Kerman was neighboring with the provinces of Khorasan, Yazd, Fars, Sistan and Hormuz and Makran provinces and most of its border areas except Fars and Hormuz desert. There was only one permanent river in it. The huge Jabal mountain range stretched northwest to southeast over an important city like Jiroft. On the other hand, geographers of the Islamic era, including Yakut Hamawi, Qazvini, Markopoulos and Hamdullah Mostofi, provided valuable information on deserts, water resources, agricultural products, minerals, and the state of roads. It is questionable that some of these sources underscore the economic importance of Kerman below the neighboring provinces. (Hamawi, 2001: 257-261, 485, 705; al- Hamawi, 1977/3: 116-122; al- Hamawi, 1977/5: 331-333; Markopoulos, 1990: 43-44; Mostofi, 1957: 170)

In general, Kerman seems to have witnessed the decline of the economic situation from the beginning to the end of the llkhanid period, except for short periods, in the light of the authority and competence of some Qara'qt rulers. (Anonymous, 1978: 235,245; Kermani Monshi, 1983: 41; Samarkand, 2004: 169; Ayat, 2004: 201-202) The present study seeks to find out the cause of this issue in light of Kerman's natural environment and geographical location.

The issue of this research is not of much background. A notable example is Mohammadpour, Khazri and Gharchanloo's (2016) research entitled "The Influence of Geographical Factors on the Political Structure of Gilan before the Russians Arrived". This study shows that the existence of natural, ethnic and cultural boundaries was the main reason for the independence and durability of local governments in Gilan and Dillman. Research on Kerman in the Ilkhanid era has focused more on the political, economic and social situation. Investigating these issues in the light of environmental impacts has no research background. Similar research is being done in other areas of Iran.

\section{Climate: The importance of tropical agriculture}

Kerman's climatic diversity can be well understood from the term "sarud and Jerome" (Kermani, 1978: 126), which refers to two different climates of cold and tropical. It seems that the Persian words "cold and hot" in the Arabic form of Maxim's plural form "sarud and groom" and are written "saurud and Jerome". Almost a quarter of Kerman province in the northern and mountainous parts of the cold region, and the southern part, from Jiroft to the Persian Gulf coast constituted the tropical region. An important consequence of this climate variability was the ability to cultivate different types of crops. Qazwini writes: "In that province be all kinds of fruits and crops like palm, orange, almond and walnut." (Qazvini, 1994: 303) Sources reports indicate the great importance of tropical in Kerman economy. In Kermani's words, it was "the property of Kerman from the tropics". (Kerman, 1947: 8) The main tropical agricultural areas of Jiroft, Reagan and Rudbar were major suppliers of Kerman's food and wealth. On the way to Kerman to Jiroft, after the mountainous area was a large plain full of saffron farms and various fruit orchards. (Markopoulos, 1969: 46) Jiroft, the most important city in the Garmsir area, was a province of fruit, with fruit orchards (Qazvini, 1994: 236) and numerous palm trees. (Al-Hamawi, 1977/2: 198) Rigan and dates were produced in Reagan (Mostofi, 1957: 171) and in the Roudbar area on the Jiroft route to Hormus, dates, pomegranates, pistachios, wheat and forage. (Markopoulos, 1990: 46-47) in Hormus Nile, Grapes, Wheat, Barley, Rice (Kermani, 1978: 128), Forage, Fruit (Markopoulos, 1990: 49-50), Sugarcane, and Dates (including the total area of three leagues was six leagues. (Mostofi, 1957: 172; Hafiz Ebro, 1999: 16-17) The tropical parts of Sirjan produced dates, sugar cane and cumin and 
were exported to other parts of the world. (Qazvini, 1994: 262) Other agricultural products were Sirjan cotton. (Mostofi, 1957: 171) Also the best fig of Kerman without mentioning a specific area in the sources mentioned. (Hamadani, 1945: 203) But since fig is a tropical fruit, it must therefore be grown in the tropical region.

Also tropical was the Silk Production Center. Silk was widespread in the cities of Bam and Narmashir in the late sixth and early seventh centuries. (Kermani, 1978: 128-129) Another author reports that most people used to bamboo and that Bam fabrics were popular in all cities. (Hamawi, 2001: 636) Markopoulos's report on the diversity of silk artifacts also confirms this. He says that Kerman girls and women wore silk fabrics of every color in animal, bird, and other motifs, made beautiful curtains for kings and sardines, and made silk robes, sheets and napkins. These textures were fascinating to Marcopoulos. (Marco polo, 1990: 45-46) Khaje Rashid al-Din Fazlullah's account of the annual influx of thousands of balloons from Bam and other parts of Kerman to Rabash Rashidi (Hamadani, 1945: 190) indicates the continued development of the silk industry in Kerman in the early eighth century.

\section{Impact of Halilrud River and Water Resources on the Jiroft Plain}

Halil River is the only and most important permanent river in Kerman province. Its length is $387 \mathrm{~km}$ and originates from the Hezar Mountain in northwest of Jiroft and flows southeast. On its way, it joins the Rivers and Rubber rivers and flows to the western margins of Hamoun and Jazmourian (Ja'fari, 1997: 276). The valley and catchment of Halilrood is bounded by Jabal Barz in the east, Sarduiyeh in the west, and Mount Hazar in the north (Fawash et al., 2008: 148). Halilrud is thus confined to a route that only the Jiroft plain benefits from.

Jiroft, like most of the time, was the most important agricultural hub and warehouse in Kerman, as it did most of the time because of its location at Halil Rood (Mostofi, 1957: 171; Muhammad ibn Ibrahim, 1964: Twenty-one). Kafi transformed Jiroft into the destination of many commercial convoys that traveled from Hormus to Jiroft and from Fars, Khorasan, Yazd, Iraq and Rome. As a result, Jiroft became a dump and warehouse for Kerman. The Qomadin neighborhood in Jiroft was the focus of travelers, merchants and merchants. The goods were stored at the Jomirat Qomadin site and then loaded onto Bardsir. According to historian Kermani, "Qomadin was a locality in Jiroft, housing the West Indies of Rome and Bahr ana Bar, the home of the travelers on the sea, the treasured treasure house, the treasure house of the great master of the East and West" (Muhammad ibn Ibrahim, 1964: 62, 100). The income from agriculture and commerce in this region was very valuable to the Qaraqatids because the dynamics of Kerman's trade depended on Jiroft. Thus, during their reign, they created economic prosperity along this route (Kerman, 1985: 35). Meanwhile, the presence of Khorasani merchants in Kerman was much more pronounced in the Mongol era than other merchants and traders. (Anonymous, 1978: 210)

Other rivers in Kerman such as Adori, Sirch and Kashit only watered a few villages and were not as important as Halilrud because they are not mentioned in Ilkhanid sources. These resources are attributed to the poor quality of Bam water due to salt availability (al-Hamawi, 1977/1: 636), and water supply to cities such as Bardsir and Khabat via the aqueduct (Hamawi, 2001: 485; al-Hamawi, 1977/1: 341) and abundance of water in Sirjan, without specifying its origin (al-Hamawi, 1977/2: 295), has indicated. The sources of this period only mention Halilrud as a large and vital river for Kerman.

\section{Mineral Resources}

Mogul period sources say the variety of mines in Kerman province. One of the valuable mineral resources of turquoise stone was that according to Marcopoulos, the Kerman Mountains were largely extracted (Markopoulos, 1990: 45) and based on the contents of the gemstone, the mountains between Yazd and Kerman were extracted. (Mohammed bin Mansour, 1956: 230) The recent report is in line with the present day location of Kerman's most important Firoozeh mine in the wells of Firoozeh and ljo around the city of Babak. Although Kerman Firouz was inferior to Neyshabur Firouz, it had an important market for sale, especially in Khata or North China. The reason was that at this time due to the destruction of Khorasan during the Mongol invasion, there was no extraction in the Neyshabur mines. (Kashani, 2007: 72) Thus, the destruction of Khorasan and especially Neyshabur by the Mongol attacks led to the entry of Kerman Firouz into the world market. Another mineral was alum. According to Qazvini, there were large mines in Kerman and were taken to other provinces. (Qazvini, 1994: 304) The characteristic alum corresponds to a potash alum derived from minerals such as kaolinite and alunite. (Sahebzadeh, 2005: 36-41) Qazvini did not specify the location of these mines, but the present location of the al-Mine mine at Ravar or Rabar and Bakr Kerman may also apply to the 7th century. (Abbaszadeh and Hezarekhani, 2010: 123-128; Ahmadipour, 2002: 85-88) Kerman's alum was the best example of alum and it was used for gastric excretion, swelling and spleen treatment. (Alavi Shirazi, 1913: 874)

Iron and Indian steel were also extracted from Dammandan (al-Hamawi, 1977/2: 1971) and most of it from the Kohbanan region (Markopoulos, 1990: 45 and 51). Markopoulos has provided a list of Kerman iron and steel products that have a particular local character: large, transparent mirrors, (Markopoulos, 1990: 51) saddle, fasting, mahazid, lantern, horse and sword, bow and arrow and all kinds of weapons. Another was built according to the customs of the region. (Markopoulo, 1969: 45) However, there are no sources in the news about the export of Kerman metal artifacts to other parts of the country, while there has been talk of sending large quantities of Fars iron products to the capital of Ilkhan. (Hamadani, 1945: 327) This lack of information does not mean that Kerman's products are of poor 
quality because Markopoulos has used the word best for most of these products. (Markopoulo, 1969: 45) Iron ore fuel was reportedly supplied by coal mines: "In the Kerman mountains it is possible to burn stone like himes and charcoal when they burn." (Qazvini, 1994: 304) Today, coal mines are located in the northern cities of Kerman, such as Zarand, Ravar, and Kohbanan, near the iron ore mines. It can be expected that as a result of the existence of coal and iron mines side by side in Kuhbanan, this area became one of the centers of iron production during the Ilkhanid period.

Tutia, or oxide, the main material of which is oxidized, was obtained in mountainous areas, Bahabad and Damandan and was dispatched to other parts of the world (Qazvini, 1994: 303; Markopoulos, 1990: 51; al-Hammui, 1977/4: 487; al-Hammui, 1977 / 2: 471) It was used to treat eye diseases. (Alavi Shirazi, 1913: 530) The present-day position of zinc mines, most of which in the Tituah Valley, includes the Caravan, Tomato, Tashko, and Bahabad is consistent with historical records.

Another valuable mineral found in Kerman was a detonation. (Kashani, 2007: 136) Emerald and turquoise stone (Nasiruddin Tousi, 1969: 118) Green as peacock neck, it is called Persian copper stone and Roman denim. (Aboureihan Beyrouni, 1995: 313-314) This description is related to malachite (copper carbonate), a decorative mineral used as a venom, antidote, eye and skin disease medication as well as bite (Nasir al-Din Toosi, 1969: 119-120) Malachite is found today in northern Kerman and in the vicinity of copper mines in Bardsir, Ravar, Rafsanjan (Sarcheshmeh), Abder, Shahrbabak and Ararani. Therefore the name denudation may be related to its existence in the mouth of copper mines. In the southern mountains of Kerman, three gold mines were mined. (Kashani, 2007: 216) Dammandan was one of the most important places where gold was extracted. (Al-Hamawi, 1977/2: 1971) There was gold in the feud of Jiroft. (Kermani, 1978: 126-127) Gold was paid to the capital as a tax and as a pillow of gold. (Juini, 2006: 532)

Other minerals were also found in Kerman. In addition to the gold mentioned earlier, copper was extracted in gold, silver, and musk (al-Hamawi, 1977/2: 471). Another mineral was the Yellow Tonight (Nasir al-Din Tusi, 1964: 121; Kashani, 2007: 139), or quartz, used to treat gastric diseases. (Nasir al-Din al-Tusi, 1964: 122) Ruby points out that nostrum (ammonium chloride) was carried from this region to other parts of the world. (Al-Hamawi, 1977/2: 1971) The newcomer was the result of the accumulation of carbon dioxide gases, so there must have been coal mining in this area. In Kerman, Azure was extracted and used in tile treatment and treatment of eye diseases, diarrhea, melancholia and old wounds. (Kashani, 2007: 137) Emery that was used to polish precious stones was also found in Kerman. (Kashani, 2007: 179)

The above data shows that in the 7th century Kerman was one of the richest provinces in the country in the 7th century. Secondly, most of the Kerman mines were located in the northern mountainous areas in the cold regions. Therefore, the life of the cold zone affected by the existence of these natural resources has been more dependent on mining and mineral production.

\section{Adjacent to Hormuz and the flourishing of business}

Kerman was on the south side with neighboring Hormuz Province. Hormuz, located near present-day Minab, was one of the main centers of Iranian maritime trade until the late seventh century and was the destination of many trade convoys from all over Iran and adjacent lands, including spices, pearls, dates, wines, horses, textiles, and many other goods. Others were exchanging. (Kermani, 1978: 128; Shabankarei, 2: 2002: 219; Mostofi, 1957: 172; Markopoulos, 1990: 48, and 43-44; Kashani, 2005: 183; Isfas, 2001: 302)

The city, later called Old Hormus, was a Kerman port or supposition that was often politically affiliated with Kerman, and its rulers paid tribute to the rulers of Kerman. Its trade with Khorasan, central and northern Iran was generally carried out by Kerman. The Kermanian report that describes Hormus as "south of Jiroft" (Kermani, 1978: 128 ) is in fact a reflection of the importance of the Hormus-Jiroft Highway. This is the path Marcopoulos has taken and described in the mid-seventh century. Thus, Hormus and Kerman needed to survive, because Hormus was the only way to reach Jiroft. And Kerman also had its trade dynamics from the boom of trade in Hormus, with Kermanshah connecting to the World Trade Network despite Hormus, and Hormus from the Jiroft highway to connect the international trade route to central Iran and then Tabriz (Markopoulos, 1989: 41) And Europe used to. In that case, Hormuz was not only a vital harbor for sea voyages crossing the Persian Gulf, but also a point where maritime and onshore trade intersected. (Kauts \& Pettak, 2005: 15) The route from Hormus to Kerman and then to Tabriz was in fact the most important trade route between southeastern Iran and northwest (the center of the Ilkhanid government).

It is clear that the existence of this highway of commerce and the flourishing business of Hormus has had important benefits for the rulers of Kerman. One example is the horse trade. About 10,000 horses were imported into southern India from Iran annually, and most of those passing through Hormuz were brought from Tuna and Cain in southern Khorasan. (Kashani, 2005: 183; Isaf, 1959: 302; Markopoulo, 1990: 43-44) Given the importance of the route of the transfer of the Tuna and Cain horses to Hormus through Kerman, its importance and impact on Kerman's trade and economy can be recognized. Other animals widely cultivated in Kerman were camels, with the camel being on the list of items to be sent to the Ilkhanian capital for taxation. Camels were very important in Iran's medieval commercial shipping fleet, especially in the hot and desert regions. (Hamadani, 1945: 93) Therefore, its cultivation in Kerman was another source of financing for the state, which would bring great wealth to the people of the region. 


\section{Barez and Bashagard Mountains, Bandits, and Kerman-Hormuz Trade Decline}

Barez and Bashagard Mountains were also effective in weakening Kerman's economic status as a pirate sanctuary. The most important Kerman mountain range, called Jabal Barez or Barjan, extends approximately 100 kilometers northwest to southeast, parallel to the Halil River valley. The prominent Jabal Range separates the Hamoun Jazmourian plain from the Shahdad salt lodge and the Lut Plain. The mountain was overlooking the plain of Jiroft and from there to Jiroft city for a day. (Kermani, 1947: 8) The height of these mountains and their dense vegetation protected the inhabitants of the mountain, such as cuffs or cages, like shields: "The mountains of Shemshak and Jabal are in the midst of the hard boughs and boughs of the tree". (Kermani, 1947: 7) Therefore, they relied on these impassable mountains for their livelihood.

The cofejs served in Barjan Mountain. Kermani adds that "there were many thieves and pedestrians there" (Kermani, 1978: 122). This means relying on them for theft and looting. They invaded on foot, and their invasions frightened the entire Kerman and Fars-Sistan frontier blocks. (Afzal Kermani, 1978: 122) During the Ilkhanid period, their power in Kerman was so great that they "went through the multitude of drums and disciplines of knowledge". (Mostofi, 1987: 531) What made the government fail to crush the cafes was their deployment in the mountains that made them difficult to access. A similar situation occurred in the southern Kerman Mountains or the Jashgar Mountains, where the Arabs lived in steel. Bashagard Mountains overlooked Jiroft on the way to Hormus, and it seems that the boom in commerce on the Hormus highway to Jiroft seems to have sparked the greed of these climbers. From here, the Arabs plundered and looted in Bashargar, Hormuz and elsewhere in Kerman province. (Secretary of the Kerman, 1983: 117; Mohammad Ibn Ibrahim, 1964: 225) The local historian of Yazd points out that during the reign of Ilkhan Khodabandeh, the steel Arabs who had settled in Jiroft and Kerman province turned to piracy. (Ja'fari, 2005: 47) Also, according to their narration in Samarqandi in Herat and Marvast and in the desert of Roudan and Rafsanjan up to the border of Khorasan, fire and plunder were set on fire. (Samarkandi, 2004: 227)

The Arab Fuladi and Nekudaries attacks were major contributors to the migration of Hormus to Jeroen Island. Ibn Battuta and Hamdollah Mostofi have made this clear. Hamdollah Mostofi, in a report on the transfer made by King Hormuz, described them as a "haram": "King Qutb al-Dinen made Tahmatan fearless and built a city on the island of Jeroen." (Mostofi, 1957: 172) Ibn al-Boutoa also considers the invasion of the Mongols (Nekudaries) as the cause of the Hormuzian emigration. (Ibn Battuta, 1997: 333) After this old Hormousian transfer lost its value as a trading hub and the Hormusian Melkos continued their business on the island of Jeroen. As a result, the island of Jerun gradually became Hormuz name.

The consequence of Hormuz's transfer to Jiron was the loss of Kerman's political dominance over Hormuz. This is stated in a late eighth-century report: "His famous positions were [Kerman], which is an island of architecture and in the world famous for a long time, though it has been separated from its present rulers." Abdul Razzaq Kermani, 1956: 50) In this report, Jeroon's belonging to Kerman is related to the distant past and may also be geographical. From that time on, Hormus destroyed the old, and could no longer restore his privileged economic position because of the past. Hafez Ebro, a historian of the late eighth and early ninth centuries, describes Hermes as "an old Hormus ruined since the departure of the Genghis." (Hafez abro, 1999: 16-17) Thus, Hormus' journey to Jiroft both in insecurity and in insecurity. The result of the abandonment of the old Hormus fell out of favor.

\section{Wilderness area, adjacent to Sistan province and invasions of Nekudaries}

One of the prominent phenomena of southeastern Iran, including Kerman, is the existence of arid and dry areas. Kerman encompassed the north, east, and south of arid and arid deserts, especially on Khorasan and Makran. (Mostofi, 1957: 170) The road to Narmashir to Farajj in the east of Kerman was in the vicinity of the deserts between Kerman and Sistan. (Al-Hamawi, 5: 1977/5: 281) Sunih from the other cities of Kerman, written by ruby, was in the middle of the same scary desert with no moving objects. (Al-Hamawi, 1977/3: 269) The existence of such deserts became a deterrent to the development of cities, villages, and commercial roads in eastern Kerman. Ways that could have been a land highway between Iran and India.

To the northeast and north, the town of Bardsir or Gawashir, the capital and largest city of Kerman (Hamavi, 2001: 485) and Khabis (Shahdad), were located alongside our desert between Kerman and Khorasan. (Al-Hamawi, 1977/2: 341; Hafiz Ebro, 1999: 16-17) Passed through Khabis, which connected Hormus to Khorasan. In this way, the Qaraqatans of Kerman sent their goods to the Mughal court. (Kermani, 1987: 6, 22, 24, 46, 53, 58, 66) One of the reasons for this peculiar commercial role was the existence of aqueducts supplying caravans. (Al-Hamawi, 1977/2: 341)

Yazd road to Kerman was also in the desert. The journey took seven days, there were only three points in that area, and in general, the area was full of bandits constantly attacking convoys. (Markopoulos, 1989: 45-44) The deserts of central Iran had the lowest geographical factors necessary for the sustenance of human life, so human communities were not formed in these areas. These areas did not even have the minimum requirements for the temporary carriage of passengers and convoys, which made them difficult to reach. These conditions made these deserts the center of banditry and crossroads that looted commercial convoys. Therefore, Kerman's barren deserts acted primarily as a deterrent to Kerman's growth and prosperity. 
Behind these deserts was on the east side of Sistan province. Sistan never completely came under Mogul's dominance and remained almost politically independent. This can be readily understood in the context of Herat's history when talking about the relationship of the Al-Kert rulers with the rulers of Sistan. (Heravi, 1973: 209- 222, 243) It seems difficult to access this area because of the vast and impassable deserts for reasons that the Mongols were unwilling to occupy Sistan. This made Sistan a good place to cross into and then settle into bandits called Nekudaries.

Nekudaries who were originally part of the Gharavonas. (Hamadani, 1959/2: 773,779, 792-793, 798-800, 890-891, 937) After disobedience of the Ilkhanids, they first believed in the Ghazan Mountains and then occupied the frontier areas of India to Multan and Lahore. (Hamadani, 1: 1959/1: 538) They attacked the eastern and southeastern states of Iran every winter. (Anonymous, 1978: 212) To plunder Kerman and Fars, they first went to the Sistan-Pashkouh region near the Lut Plain and then attacked Kerman and Fars on thirteen routes. (Anonymous, 2135: 1978)

The Nekudaries used Sistan as a base to attack Kerman, Fars, and Hormus. In 674 AH, for example, they fled to Sistan after the invasion of Jiroft and Hormuz and the looting of Iraqi and Azerbaijani caravans in Jiroft. (Anonymous, 1978: 239-240) Also in $678 \mathrm{AH}$ they invaded Sistan to Reagan, Bam, and Jiroft, inflicting extensive damage, and from there they went to Hormus and looted the merchants' property. Then they went to the tropical regions of Fars and after defeating the Persian Army in Karbala they went to Kerman and returned to Sistan via Rudbar and Jiroft. (Anonymous, 1978: 205-208) They left Kerman in 680 AH and returned to Sistan. (Ayatollah, 2004: 116)

The invaders' invasion was not limited to looting the property of ordinary people or "businessmen" (Anonymous, 1978: 205-206). They were destroying what was not portable (Anonymous, 1978: 211), "burning up all that they had, and taking away from the sheep and goats a sheep, and leaving them" (Wasaf, 1959: 371), and enslaved the farmers and ordinary people. (Anonymous, 2135: 1978; Markopoulos, 1990: 90)

The most important result of these attacks was the loss of regional security and trade routes. (Written, 1956: 5; unnamed, 1978: 212-213) Their looted raids destroyed the capital of farmers, traders and merchants. Many people left their farms and villages and left home. (Katab Yazdi, 1978: 213; Wassaf, 1959: 201) The danger of the dwarfs eventually led the Ilkhanid government to build towers and barrows in Kerman and Fars. (Wassaf, 1959: 203; anonymous, 1978: 212-213) But this action was not fruitful, and the attacks of the farmers continued until the late seventh century.

\section{Conclusion}

Keeping distance from what is called geographical algebra, it can be concluded from the evidence that environmental phenomena interacted with human decisions and practices in Kerman in the seventh and eighth centuries. This effect can be seen in two different respects. On the one hand, water resources, the tropical climate and proximity to the Persian Gulf contributed to the boom of economic life. The tropical climate with water resources such as Halilrood made it a dynamic hub of agriculture through the activities of rural communities in favorable areas such as the Jiroft Plain. At the same time, the geographical proximity of the area to the city of Hormus on the Persian Gulf enabled the important trade route south of the country to pass through Jiroft and Kerman and reap its benefits. The existence of various mineral resources in the often cold regions and their exploitation also contributed to the dynamics of economic life, especially trade. But other environmental factors, such as desert areas, proximity to Sistan, and the Bars and Jashgar Mountains, further contributed to the weakening of economic life. Bandits and the Kafaj Escaping Center (Café) and Steel Arabs looted caravans and rural areas in the refuge of Jabal Bareh and the Jasharag Mountains, and in particular made the Hormus Road to Jiroft and Kerman unsafe. Mughal evacuation centers like the Nekudaries, taking refuge in Sistan and its eastern regions, took advantage of Kerman's defenseless desert position and during the seventh century plundered and invaded much of southern Iran from Kerman and Fars to Hormuz. They shook hands. As a result of this insecurity, the hermits of Hormus left the city of Hormus (Old Hormus) and emigrated to the island of Jerun (New Hormus), which contributed to the overall decline of Kerman's trade. The different impact of these geographical factors seems to have contributed to Kerman being second in importance in terms of economic status compared to other provinces in the Ilkhanid period.

\section{References}

Abbaszadeh, M \& Hezarekhani, A. (2010), "Mapping of hydrothermal alterations using ASTER images in the Kerman Rubber Zone", Journal of Earth Sciences, No. 78, pp123-128.

Ahmadipour, H. (2002), "The Origin of the Kaolin Storage West of Deh Bakri (Kerman Province)" Sixth Iranian Geological Society Conference, Kerman University, 85-88. Retrieved of https://www.symposia.ir/CISEG06

Ahmadvand, A. (2009), "Reflection on the Teaching and Research of Historical Geography in Iran", Quarterly Journal of Islamic History, No. 40, 41-63. Retrieved of http://hiq.bou.ac.ir/article_5665.html

Al-Hamawi, Shahabuddin Abi Abdullah Ya'qub bin Abdullah (1977), Mo'jam al-Baladan, Beirut: Darshad.

Alavi Shirazi, M. H. (1913), Aladiyeh Reservoir: A Dictionary of Traditional Medicines, Kanpur: Bhagwan Dial

Anonymous (1978), History of the King of the Qaraqatians, with the correction and correction of Mohammad Ibrahim Bastani of Paris, Tehran: Foundation of Culture.

Ayati, A. M. (2004), Writing History of Wisaf, Tehran: Humanities and Cultural Studies Institute.

Bourouni, A. (b. 1995), al-Jawahir fi al-Jawahar, scholar Youssef Al-Hadi, Tehran: Al-Nashr and Al-Ali al-Qaqafi. 
Fawash, E \& Garson, D. (2008) "Geomorphic Dynamics and Archaeological Survey of the Halil Valley", Proceedings of the First International Conference on Halil Basin Civilization. Kerman: Publication of Kerman Province's Heritage of Crafts and Tourism, 145-166. Retrieved of https://www.gisoom.com/book/1935799/

Ghazvini, Z. (1994), The Works of Aalblad and Akbar News, Translated by Jahangirmira Qajar, Tehran: Amirkabir Publications.

Hafez Ebro, Sh. (1999), Geography of Hafez Ebro, Correction by Sadegh Sajjadi, Tehran: Mirror Mirror Publications.

Hamadani, F. (1945), Rashidi's Correspondence, Collection of Rumi, by Mohammed Abraghi, to Try and Correct Muhammad Shafi'i, Punjab: ljukishnal Paris Lahore.

Hamadani, K. (1959), Jama'at al-Tawarikh, by the efforts of Bahman Karimi, Tehran: Iqbal Publications.

Hamavi, Sh. (2001), Mojammad al-Baladan, Translated by Ali Naghi Monzavi, Tehran: Cultural Heritage Organization Publications.

Heravi, S. (1973), History of Herat, Corrected by Mohammad al-Zubir al-Sadiqi, Tehran: Khayyam Publications Bookstore.

Ibn Battuta, M. (1997), Travelogue, Tehran: Aegh Publications.

Jafari, A. (1997), Iranian Geology-Rivers of Iran, Volume Three, Tehran: Geographical and Cartographic Organization of Geology.

Jafari, J., (2005), History of Yazd, Edited by Iraj Afshar, Tehran: Scientific and Cultural Publications.

Jouini, A. (2006), The History of Jawani Jahoshi, Tehran: Dastan Publications.

Kashani, A. (2005), History of Oljayto, edited by Mahin Hambley, Tehran: Scientific and Cultural Publications.

Kashani, A. (2007), Aras al-Jawahar and Nafis al-Atayeb, Tehran: Al-Maali Publications.

Katab Yazdi, A. (1979), The New History of Yazd, by the efforts of Iraj Afshar, Tehran: Iran Zaman and Amir Kabir Culture Publications. Kateb, M. (1956), The History of Al-Muzaffar, Designed by Abdolhossein Nawaii, Tehran: Ibn Sina Bookstore.

Kauts, R \& Potak, R (2005), Hormuz in the Sources of the Yuan and Ming Courses, Translated by Mehrdad Vahdati, Tehran: Academic Publishing Center.

Kermani, A. (1947), The Exodus of Kerman's Events or the History of Afzal, Edited by Mehdi Bayati, Tehran: University Press.

Kermani, A. (1956), Remarks by King Nematollah Wali, edited by Jean Ouben, Tehran: Institute of Iran and France.

Kermani, A. (1978), Agdali-ali Lalmuq-e-Ali, Edited by Ali Mohammad Ameri Naeini, Tehran: Roozbehan Publications.

Kermani, N. (1983), Samt al-Ali Lahzahra Alia, Correcting Abbas lqbal, Tehran: Mythology.

Kermani, N. (1985), Nassem al-Sahar and Lateim al-Akhbar, Tehran: Information Publication.

Marco, P. (1969), Marcopoulos's Letterhead, Translated by Mansour Sajjadi, Tehran: Boali Publications.

Mohammad, I. (1964), The History of the Seljuks and Ghaz in Kerman, by Ancient Parisian, Tehran: Tahori Bookstore.

Mohammad, M. (1956), The Jeweler, by Manouchehr Sotoudeh, Tehran: Iran Zaman Culture Publications.

Mostofi, H. (1957), Najeh al-Qoloub, by the efforts of Mohammad Dabir Siyaghi, Tehran: Tahari Library Publications.

Mostofi, H. (1985), Excerpted, Edited by Abdolhossein Navaei, Tehran: Amirkabir Publications.

Nasiruddin Tousi, M. (1969), Tansokh letter, Ilkhani, Tehran: Foundation for Iranian Culture.

Papeli Yazdi, M. H. (1994), "Geographical Algebra or Environmental Capabilities", Geophysical Research Quarterly, No. 35, Isfahan, University of Isfahan, pp. 3-16.

Sahebzadeh, B. (2005), "Scientific Skills in Teaching Earth Sciences", Growth Journal of Earth Sciences Education, No. $42,36-41$. Retrieved of https://mag.roshd.ir/zamin/Archive/2

Samarkhandi, K. (2004), Informed Saadin and Bahraini Assembly, by Abdolhossein Navaei, Tehran: Humanities and Cultural Studies Institute.

Shabankarei, M. (2002), The Anastasios, edited by Mir Hashim Mohaddess, Tehran: Amirkabir Publications.

Wassaf al-Hazra, F. (1959), History of Wassaf al-Hazra, by Mohammad Mehdi Esfahani, Tehran: Ibn Sina Library and Jafari Tabriz Library.

How to cite this article: Mohammadi Roudsari, M. P., Rasouli, A., Asad Pour, H., \& Gholizadeh, M. R. (2020). The Impact of Environmental Factor on Kerman Economic Development in Ilkhanid Era. Religación. Revista De Ciencias Sociales Y Humanidades, 5(23). Retrieved from http://revista.religacion.com/index.php/religacion/article/view/615

Submitted: 28 December 2019 Accepted: 04 March 2020 Published: 31 March 2020

Religación. Revista de Ciencias Sociales y Humanidades is a peer-reviewed open access journal published by CICSH-AL Centro de Investigaciones en Ciencias Sociales y Humanidades desde América Latina |Religación| 